\title{
A history of Egypt's social spring
}

Written by: Anne-Lise Prigent, OECD Observer

Last update: 21 November 2018

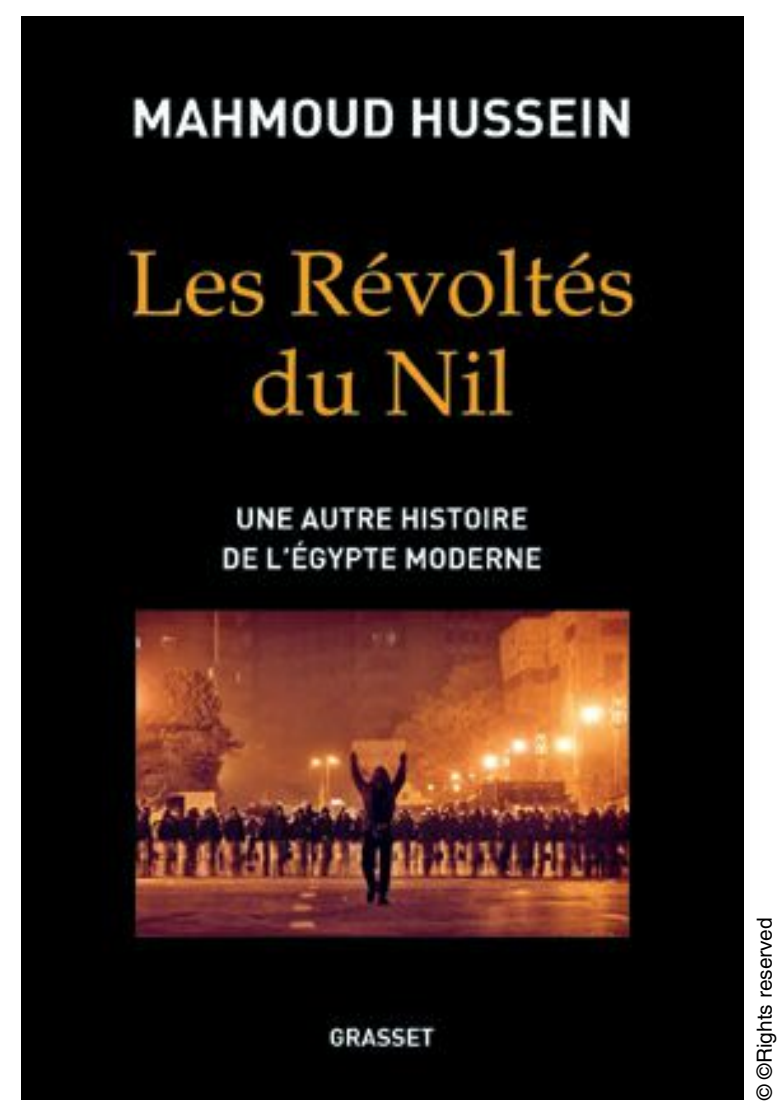

A history of Egypt's social spring

To understand the 2011 Egyptian Arab Spring, we need to view it as the culmination of a series of uprisings within the country's long history. From this vantage point we can start to see the gradual acquisition of free will and social awareness.

Les Révoltés du Nil : Une Autre Histoire de l'Égypte Moderne (available in French only) reads like a detective novel. Remarkably, it is written from the point of view of the people, telling the turbulent story of Egypt since the end of the eighteenth century in a fascinating exposé of the birth of its people's social awareness. 
From the Pharaohs to the Sultans, submission to a power perceived as celestial and therefore sacred was absolute. The individual simply did not exist. The first crack in the armour came with the insurrection against Napoleon. This existential clash coincided with the discovery of a new model-European and secular.

But one occupying power gave way to another, from the short-lived return of the Ottomans and the Mamluks in 1801 to the period of British rule that followed the reinvention of the State of Egypt under Muhammad Ali and Isma'il Pasha.

Faced with the colonial order, the patriotic uprising of 1919 was a magical moment that belonged to the people, says Mahmoud Hussein. What would happen to the emergence of this newfound self-awareness? Turning the pages, we discover that it was soon to be snatched away again. From the arrival of Nasser in 1956 to the fall of Mubarak in 2011, we read the tumultuous story of a patriotic, then a social, conscience.

In an unprecedented feat, Mubarak's regime was toppled-peacefully-in just three weeks. The people now view those who govern them as deconsecrated, mere administrative agents who must be accountable to them for their actions. On Tahrir Square in Cairo, the incredible people's uprising freed the collective conscience. "Everybody spoke in their own name to speak a universal truth."

What happened to this collective wave of hope? This compelling work helps us decode the story.

COECD Observer No 316, Q4 2018

\section{References}

Hussein, Mahmoud (2018), Les révoltés du Nil : Une autre histoire de l'Egypte moderne, Grasset, Paris https://www.grasset.fr/les-revoltes-du-

$\underline{\text { nil-9782246790778 }}$ 